\title{
Effect of fibrolytic enzymes on lactational performance, feeding behavior, and digestibility in high-producing dairy cows fed a barley silage-based diet
}

\author{
Basim Refat, ${ }^{*}$ David A. Christensen, ${ }^{*}$ John J. McKinnon, ${ }^{*}$ Wenzhu Yang, † Aaron D. Beattie,‡ \\ Tim A. McAllister, $†$ Jong-Su Eun,§ Gamal Ali Abdel-Rahman,\# and Peiqiang Yu*1 \\ *Department of Animal and Poultry Science, College of Agricultural and Bioresources, University of Saskatchewan, Saskatoon, \\ Saskatchewan S7N 5A8, Canada \\ †Lethbridge Research and Development Center, Agriculture and Agri-Food Canada, Lethbridge, Alberta T1J 4B1, Canada \\ $\ddagger$ Crop Development Center, Department of Plant Sciences, College of Agriculture and Bioresources, University of Saskatchewan, \\ Saskatoon, Saskatchewan S7N 5A8, Canada \\ §Biotechnology Research Institute, CJ CheilJedang, Gyeonggi 16495, South Korea \\ \#Department of Animal Production, Faculty of Agriculture, Zagazig University, Zagazig 44511, Egypt
}

\begin{abstract}
The objectives of this study were to evaluate the effects of pretreating dairy cow rations with a fibrolytic enzyme derived from Trichoderma reesei (FETR; mixture of xylanase and cellulase; AB Vista, Wiltshire, UK) on lactation performance, digestibility, and feeding behavior in response to feeding a barley silage-based diet. Before starting the dairy trial, in vitro incubations were conducted to determine whether the addition of FETR would have an effect on these animal performance characteristics when applied to a barley silage-based diet for dairy cows. The dairy trial was performed using 8 Holstein dairy cows. The cows were blocked by parity and assigned randomly to 1 of 4 treatments: $0,0.5$, 0.75 , and $1 \mathrm{~mL}$ of FETR/ $\mathrm{kg}$ of dry matter (DM) diet in a replicated Latin square design. The pretreatment was applied to the complete diet during the mixing process. The experimental period continued for $22 \mathrm{~d}$, with each experimental period consisting of a 16-d adaptation period and a $6-\mathrm{d}$ sampling period. The daily feed intake of each individual cow was monitored using Insentec feed bins (RIC system, Insentec, Marknesse, the Netherlands). Feeding behavior characteristics were measured during the entire sampling period using the feed bin attendance data. Milk samples were collected in the last $3 \mathrm{~d}$ of each experimental period. The addition of FETR linearly increased the in vitro DM digestibility and tended to improve the in vitro digestibility of barley silage. There was a cubic effect of the enzyme levels on the total-tract DM and neutral detergent fiber digestibility. Maximal digestibility was
\end{abstract}

Received November 27, 2017.

Accepted May 5, 2018.

${ }^{1}$ Corresponding author: peiqiang.yu@usask.ca reached at $0.75 \mathrm{~mL}$ of FETR $/ \mathrm{kg}$ of TMR. The milk fat yield, fat-corrected milk, and energy-corrected milk quadratically responded to the incremental levels of FETR. The milk protein percentage linearly improved in response to FETR. Increasing FETR levels resulted in a quadratic effect on feed efficiency. There was no effect of FETR level on feeding behavior. In conclusion, pretreating dairy cow barley silage-based diet with 0.75 $\mathrm{mL}$ of FETR/kg of TMR increased the milk production efficiency of dairy cows fed diet containing 34\% barley silage (DM basis). The positive effect of adding FETR could benefit the dairy industry in western Canada, where barley silage-based diets are common.

Key words: barley silage, dairy cow, feed efficiency, feeding behavior, fibrolytic enzyme

\section{INTRODUCTION}

Dairy cows are able to utilize the digestible nutrients from forages and convert them into milk and meat products for humans. The rate and extent of forage digestion in dairy cows are lower than those of concentrates, which limits feed intake and performance of dairy cows (Reynolds, 2000). Thus, it is important to improve forage digestibility to increase milk production level. Fibrolytic enzymes are used as feed additives in ruminant diets to enhance forage fiber digestibility and lactational performance of dairy cows. Addition of enzymes directly to the feed enhances the digestibility of DM and NDF (McAllister et al., 1999; Kung et al., 2000; Yang et al., 2000). However, there are inconsistent results regarding the effect of providing fibrolytic enzymes to ruminant diets on dairy cow performance (Bernard et al., 2010; Chung et al., 2012; Dean et al., 2013). Thus, the use of fibrolytic enzymes as feed additives has not yet been extensively adopted in commercial dairy farms. Nevertheless, due to a continuous increase in feed costs, it is essential to reconsider and 
refine the use of enzymes as feed additives in ruminant diets as a strategy to improve feed efficiency and decrease the cost of milk production (Titi, 2003).

Whole-crop barley (Hordeum vulgare L.) silage is a main forage component of dairy and beef rations in western Canada because the crop is well adapted for production in this region (Wallsten and Hatfield, 2016). In a previous study, 3 barley forage varieties were selected based on their varying rate of in vitro NDF digestibility to study the effects of barley silage on growing performance of beef cattle (Nair et al., 2017). From the results of this study, it was found that all barley varieties, despite differences in NDF digestibility, have a similar effect on feed efficiency. However, other factors did substantially affect forage quality and digestibility, such as the environmental temperature and the stage of maturity at harvest. The large differences in nutritional quality among forage barley varieties suggest that it is necessary to apply other approaches to improve forage digestibility, such as using fibrolytic enzyme products with high activity (xylanase and cellulase) for improving the digestibility of barley silage. To our knowledge, there is little documentation of the lactation performance response by cows to fibrolytic enzymes applied to barley silage. This study aimed to evaluate the effects of supplementing a fibrolytic enzyme product applied directly to a barley silage-based diet fed to dairy cows during mid lactation on milk yield, milk composition, nutrient intake and digestibility, and feeding behavior.

\section{MATERIALS AND METHODS}

\section{In Vitro Study}

An in vitro study was conducted to determine whether the addition of fibrolytic enzymes derived from Trichoderma reesei (FETR; mixture of xylanase and cellulase; AB Vista, Wiltshire, UK) would have an effect on animal performance when applied to a barley silage-based diet for dairy cows. This product was selected based on its high fibrolytic enzymatic activities (xylanase and cellulase). The product is a mixture of xylanase (EC 3.2.1.8; xylanase activity = $350,000 \mathrm{BXU} / \mathrm{g}$, where $1 \mathrm{BXU}$ is the amount of enzyme that is able to release $0.06 \mu \mathrm{mol}$ of xylose equivalent from birchwood xylan per minute) and cellulase (EC 3.2.1.8; endoglucanase activity $=10,000 \mathrm{ECU} / \mathrm{g}$, where $1 \mathrm{ECU}$ is the amount of enzyme that is able to release $0.06 \mu \mathrm{mol}$ of glucose from medium-viscosity carboxymethyl cellulose per minute). The enzyme was tested on barley silage harvested at mid-dough stage with $41 \%$ DM content. The samples of barley silage were oven dried at $55^{\circ} \mathrm{C}$ for $48 \mathrm{~h}$. The dried samples were ground through a 1-mm screen for the chemical analysis and the in vitro study (Christy and Norris mill 8-in. lab mill, Christy Turner Ltd., Chelmsford, UK). The detailed chemical composition of barley silage is shown in Table 1. The cumulative gas production of silage treated with different doses of enzyme was measured using the batch culture technique as described by Eun et al. (2007). Enzyme doses (0.00, 0.25, 0.50, 0.75, 1.00, and $1.25 \mathrm{~mL}$ of FETR/kg DM of silage) were added directly onto the substrate immediately before addition of rumen fluid and buffer medium. The enzyme added to an approximately 0.5 -g sample ( $1 \mathrm{~mm}$ grind size) of dried silage was weighed in triplicate into acetonewashed filter bags (F57, Ankom Technology, Macedon, $\mathrm{NY}$ ). The bags were sealed and placed into $100-\mathrm{mL}$ serum bottles. All dosages of enzymes were diluted with distilled water $(0.1 \%$ FETR $)$. The volume of diluted enzyme solution was equal for all doses. In addition, an equal volume of distilled water was added to serum bottles to serve as the control. Two experimental runs were performed on different days. Ruminal fluid was collected $2 \mathrm{~h}$ after feeding from 2 rumen-cannulated Holstein cows. The cows were fed diets formulated with $34.1 \%$ barley silage, $16.1 \%$ chopped alfalfa hay, $30.1 \%$ lactation concentrate pellet, and $19.7 \%$ barley grain to meet the requirements for lactating dairy cows producing $40 \mathrm{~kg}$ of milk (National Research Council, 2001). Each serum bottle received $15 \mathrm{~mL}$ of strained ruminal fluid and $45 \mathrm{~mL}$ of McDougall's buffer, during which oxygen-free $\mathrm{CO}_{2}$ was flushed. Three blanks that contained $60 \mathrm{~mL}$ of medium without feed samples were used for each incubation time. Sealed bottles were incubated in an oscillating shaker at $39^{\circ} \mathrm{C}$ with an oscillation speed of $125 \mathrm{rpm}$ for $48 \mathrm{~h}$. Headspace gas production was measured at $3,6,9,12,24$, and 48 $\mathrm{h}$ by inserting a 23 -gauge $(0.6 \mathrm{~mm})$ needle attached to a pressure transducer (model PX4200-015GI; Omega Engineering Inc., Laval, QC, Canada) connected to a visual display device (Data Track, Christchurch, UK). Pressure values, corrected for the gas released from the blanks, were used to generate volume estimates using the equation described by Mauricio et al. (1999).

\section{Experimental Cows and Diets}

A lactational performance study was conducted using 8 mid-lactating Holstein dairy cows (average parity = $2.8 \pm 1.2$ ) consisting of 4 primiparous cows (average $\mathrm{BW}=618 \pm 61 \mathrm{~kg} ; \mathrm{DIM}=118 \pm 17)$ and 4 multiparous cows (average $\mathrm{BW}=738 \pm 13 \mathrm{~kg} ; \mathrm{DIM}=137 \pm$ 5.4). All experimental procedures used in this experiment were approved by the University of Saskatchewan Animal Care Committee. All cows were housed at the Rayner Dairy Research and Teaching Facility farm, University of Saskatchewan (Saskatoon, SK, Canada). 
The experimental design was a double $4 \times 4$ Latin square with four 22-d periods. The cows were housed in 1 pen in a freestall barn. The pen was equipped with 8 Insentec feed bins (Insentec BV, Marknesse, the Netherlands). The Insentec system was set to allow 1 cow to access 1 feed bin during the entire experiment.

The cows were fed ad libitum a TMR (allowing for a $10 \%$ refusal) consisting of $34.1 \%$ barley silage, $16.1 \%$ alfalfa hay, $19.7 \%$ barley grain, and $30.1 \%$ concentrate on a DM basis. The diets were formulated using NDS Professional ration formulation software (version 3; RUM\&N, NDS Professional, Reggio Nell'Emilia, Emilia-Romagna, Italy) to provide an adequate amount of ME and MP for dairy cows 120 DIM producing $40 \mathrm{~kg}$

Table 1. Ingredient and chemical composition (\% unless noted) of the TMR and barley silage used for the 4 exogenous fibrolytic enzymesupplemented diet treatments

\begin{tabular}{lc}
\hline Item & Amount \\
\hline Ingredient (DM basis) & \\
Barley silage & 34.1 \\
Alfalfa hay & 16.1 \\
Barley grain, 75\% processing index ${ }^{1}$ & 19.7 \\
Barley grain, ground & 6.6 \\
Corn grain, ground fine & 2.8 \\
Canola meal & 7.8 \\
Soybean meal & 2.8 \\
Peas & 1.7 \\
Corn distillers, dehydrated & 0.6 \\
Wheat, ground & 1.1 \\
Corn gluten meal & 0.6 \\
Acid buffer & 0.3 \\
Sodium bicarbonate & 0.5 \\
Calcium phosphate & 0.0 \\
Limestone & 0.8 \\
Fat tallow & 0.6 \\
Premix & 0.8 \\
Salt, white & 0.3 \\
Beet pulp pellets & 1.8 \\
Rp10 palmitic & 1.0 \\
Chemical composition of silage & \\
DM & 41.9 \\
CP (\% of DM) & 12.3 \\
Starch (\% of DM) & 21.7 \\
NDF (\% of DM) & 45.8 \\
ADL (\% of DM) & 4.4 \\
24-h in vitro NDF digestibility & 19.6 \\
Chemical composition of diet & \\
DM & 55.1 \\
OM (\% of DM) & 93.3 \\
CP (\% of DM) & 16.2 \\
NDF (\% of DM) & 29.5 \\
288-h indigestible NDF (\% of DM) & 14.3 \\
Potentially digestible NDF (\% of DM) & 15.2 \\
\hline
\end{tabular}

${ }^{1}$ Processing index is the bushel weight of the barley after processing expressed as a percentage of the bushel weight before processing.

${ }^{2}$ Composition: calcium $=16 \%$; phosphorus $=8.0 \%$; chloride $=10.4 \%$; sodium $=7.6 \%$; potassium $=1.8 \%$; sulfur $=1.0 \%$; magnesium $=4.5 \%$; copper $=535 \mathrm{mg} / \mathrm{kg} ;$ zinc $=2,100 \mathrm{mg} / \mathrm{kg} ;$ manganese $=1,500 \mathrm{mg} / \mathrm{kg} ;$ iron = maximum $1,050 \mathrm{mg} / \mathrm{kg}$; selenium $=16 \mathrm{mg} / \mathrm{kg}$; iodine $=45 \mathrm{mg} /$ $\mathrm{kg}$; cobalt $=16 \mathrm{mg} / \mathrm{kg}$; vitamin $\mathrm{A}=330,000 \mathrm{IU}$; vitamin $\mathrm{D}=60,000$ $\mathrm{IU}$; vitamin $\mathrm{E}=2,500 \mathrm{IU}$.

${ }^{3}$ Palmitic acid (C16-0). of milk according to NRC (2001). Animals were fed twice daily at approximately 0900 and $1700 \mathrm{~h}$ and were milked 3 times a day at approximately 0430,1230 , and $1830 \mathrm{~h}$. The experimental period lasted for $22 \mathrm{~d}$, with each experimental period comprising a 16-d adaptation period and a 6 -d sampling period.

Animals within each square were assigned to 4 experimental treatments. The experimental treatments consisted of the basal TMR (control; Table 1) and the basal TMR supplemented with 3 levels of FETR: 0.5, 0.75 , and $1 \mathrm{~mL}$ of FETR/ $\mathrm{kg}$ DM of TMR. The enzyme mixture was prepared twice per week. The enzyme liquid (diluted in water; 1:5 ratio $\mathrm{vol} / \mathrm{vol}$ ) was sprayed onto the TMR while mixing. Then all diets were kept for approximately $1 \mathrm{~h}$ before the start of feeding to increase enzyme efficacy.

The yield of milk was recorded at each milking during the last week of each experimental period. Milk samples were collected in the last $3 \mathrm{~d}$ of each sampling period (d 20, 21, and 22), preserved with potassium dichromate, and tested at CanWest DHI (Edmonton, $\mathrm{AB}$, Canada) for milk fat, protein, lactose, MUN, and TS using infrared spectroscopy (MilkoScan 605, Foss Electric, Hillerød, Denmark; AOAC, 1990, method 972.16).

\section{Nutrient Intake and Digestibility}

Feeding time and daily feed intake of each individual cow were monitored using Insentec feed bins. Feed samples and orts were collected twice weekly for DM adjustment. From d 19 to 22, TMR and ort samples were collected and stored at $-20^{\circ} \mathrm{C}$ for later analysis. The refusal and TMR samples were thawed and dried at $60^{\circ} \mathrm{C}$ for $48 \mathrm{~h}$ for nutrient analysis. Samples were ground through a 1-mm screen (standard model 4; Arthur H. Thomas Co., Philadelphia, PA) and composited by period for analysis of OM, NDF, indigestible NDF (iNDF), and CP. The iNDF content of each sample was determined following in situ incubations for $12 \mathrm{~d}$ in the rumen (Ahvenjärvi et al., 2000).

A fecal grab sample (300-500 g on a fresh basis) was collected twice daily immediately before feeding time for $4 \mathrm{~d}$ at the end of each period. All fecal samples were mixed and pooled per cow, and a subsample was stored at $-20^{\circ} \mathrm{C}$ for later analysis. Total-tract digestibility of DM, OM, NDF, and potentially digestible NDF (pdNDF) was estimated using iNDF as an internal marker (Ahvenjärvi et al., 2000).

\section{Feeding Behavior}

Feeding behavior characteristics were assessed in this study in the last $6 \mathrm{~d}$ of each experimental period us- 
ing feed bin attendance data. The parameters recorded included feed intake, daily eating time, duration and frequency of bunk attendance, and meal frequency. The meal was defined as a visit to the bunk followed by an absence of $5 \mathrm{~min}$ or greater. The eating rate was calculated by dividing the amount of individual intake by the eating time. The system was monitored daily for proper operation.

\section{Chemical Analysis}

All frozen TMR, refusals, and fecal samples were thawed overnight at room temperature and dried at $55^{\circ} \mathrm{C}$ for $72 \mathrm{~h}$. All samples were ground through a 1-mm screen using a Christy and Norris 8-in. lab mill (Christy Turner Ltd.) for use in chemical analyses. Dry matter (method 930.15), ash (method 942.05), crude fat (method 2003.05), and CP (method 990.03) were analyzed according to AOAC International (2000). For estimation of $\mathrm{CP}, \mathrm{N}$ was determined using a Leco FP 528 nitrogen combustion analyzer (Leco, St Joseph, $\mathrm{MI})$. Values of ADF, NDF, and ADL were also analyzed according to the Van Soest et al. (1991) method combined with an ANKOM A200 filter bag technique (Ankom Technology Corp., Macedon, NY). Amylase and sodium sulfite were used in the NDF analysis.

\section{Calculations and Statistical Analysis}

Total-tract pdNDF digestibility was calculated according to Fustini et al. (2017). The digestibility of pdNDF was expressed as follows:

$$
\begin{gathered}
\text { pdNDF digestibility, } \% \text { pdNDF }= \\
100-[(\text { dietary iNDF } / \text { fecal iNDF }) \\
\times(\text { fecal pdNDF concentration/dietary pdNDF })] .
\end{gathered}
$$

The data were analyzed using PROC MIXED of SAS 9.4 (SAS Institute Inc., Cary, NC). Data for intake, digestibility, milk production, and feeding behavior were analyzed with the following model:

$$
Y=\mu+T_{i}+P_{j}+S_{k}+C_{l(k)}+e_{i j k l}
$$

where $Y$ is the dependent variable, $\mu=$ the overall mean; $T_{i}=$ the fixed effect of the $i$ th treatment $(i=1$ to 4$) ; P_{j}=$ the fixed effect of the $j$ th period ( $j=1$ to 4$)$; $S_{k}=$ the random effect of the $k$ th square $(k=1$ to 2$)$; $C_{l(k)}=$ the random effect of the $l$ th cow within square ( $l=1$ to 4$)$; and $e_{i j k l}=$ random residual error, assumed to be normally distributed.
The cumulative gas production, in vitro DM, and NDF digestibility data were analyzed as a randomized complete block design. The statistical model used to analyze these parameters was

$$
Y_{i j}=\mu+T_{i}+B_{j}+e_{i j},
$$

where $Y=$ an observation of the dependent variable; $\mu=$ the population mean for the variable; $T_{i}=$ the treatment effect as a fixed effect; $B_{j}=$ block effect with experimental run $(\mathrm{n}=2)$ as a random effect; and $e_{i j}$ $=$ the random error associated with the observation. Results are reported as least squares means. Polynomial contrasts were used to determine the effect (linear, quadratic, and cubic) of increasing enzyme application.

\section{RESULTS AND DISCUSSION}

Table 2 shows the effect of FETR levels on in vitro gas production and DM and NDF digestibility. There was no effect $(P>0.10)$ of FETR levels on in vitro gas production. There was a linear effect $(P=0.02)$ of enzyme levels on in vitro DM digestibility over $48 \mathrm{~h}$ of incubation. The results showed that enzyme level also tended to have a linear effect $(P=0.08)$ on in vitro NDF digestibility over $48 \mathrm{~h}$ of incubation.

The effect of FETR levels on intake and digestibility are presented in Table 3, which indicates that FETR levels did not alter DM, OM, or NDF intake $(P>0.10)$ in dairy cows. These results are in line with previous studies that noted no effect of exogenous fibrolytic enzyme addition on DMI of dairy cows during different stages of lactation (Bernard et al., 2010; Chung et al., 2012; Dean et al., 2013). However, some studies (Beauchemin et al., 2000; Gado et al., 2009) reported a positive effect of exogenous fibrolytic enzyme with high cellulase or xylanase activity on DMI. The intake of forage-based diets by dairy cows is often controlled by rumen fill and the rate of degradation (Allen, 1996; Poppi, 2011). The DMI of early-lactation dairy cows is controlled by gut fill when cows are in negative energy balance (Dado and Allen, 1995). However, the DMI of mid- and late-lactation cows is not restricted by physical fill but rather is controlled by the metabolic processes of the cow to use absorbed nutrients for production requirements (Urrutia and Harvatine, 2017). Consequently, reliant on level of production and the lactation stage, the dairy cows would be likely to respond to a lesser extent due to increasing the DMI as a consequence of improving the fiber digestibility of the diet (Oba and Allen, 2000). Chow et al. (2008) found that feeding cows barley silage with high NDF digest- 
Table 2. Effect of exogenous fibrolytic enzyme derived from Trichoderma reesei (FETR; mixture of xylanase and cellulase) on asymptotic cumulative gas volume $(\mathrm{mL} / \mathrm{g}$ of $\mathrm{OM})$ and nutrient digestibility in barley silage

\begin{tabular}{|c|c|c|c|c|c|c|c|c|c|c|}
\hline \multirow[b]{2}{*}{ Item } & \multicolumn{6}{|c|}{ Enzyme level (mL of FETR/kg of DM of silage) } & \multirow[b]{2}{*}{ SEM } & \multicolumn{3}{|c|}{ Polynomial contrast value } \\
\hline & Control (0) & 0.25 & 0.50 & 0.75 & 1.00 & 1.25 & & Linear & Quadratic & Cubic \\
\hline \multicolumn{11}{|c|}{$\begin{array}{l}\text { Asymptotic cumulative gas } \\
\text { volume }(\mathrm{mL} / \mathrm{g} \text { of } \mathrm{OM})\end{array}$} \\
\hline $3 \mathrm{~h}$ & 18.8 & 34.3 & 30.6 & 26.0 & 23.6 & 24.7 & 4.96 & 0.870 & 0.174 & 0.163 \\
\hline $6 \mathrm{~h}$ & 36.3 & 55.4 & 53.4 & 46.0 & 39.4 & 44.2 & 7.50 & 0.811 & 0.218 & 0.175 \\
\hline $9 \mathrm{~h}$ & 53.3 & 74.1 & 73.7 & 65.1 & 56.6 & 65.7 & 9.17 & 0.990 & 0.289 & 0.177 \\
\hline $48 \mathrm{~h}$ & 133.1 & 150.5 & 140.1 & 151.4 & 131.3 & 138.7 & 6.77 & 0.760 & 0.184 & 0.304 \\
\hline \multicolumn{11}{|c|}{ Nutrient digestibility (\%) } \\
\hline 48-h DM & 58.5 & 62.0 & 60.5 & 62.5 & 61.7 & 62.9 & 4.95 & 0.018 & 0.303 & 0.133 \\
\hline 48-h NDF & 34.7 & 40.8 & 36.8 & 39.9 & 39.1 & 40.8 & 2.96 & 0.081 & 0.561 & 0.223 \\
\hline
\end{tabular}

ibility had no effect on DMI during the mid-lactation stage, but the cows tended to gain more weight.

The response of DM, OM, and NDF digestibility to the increasing level of FETR was cubic $(P<0.01$; Table $3)$, where the intermediate dosage $(0.75 \mathrm{~mL}$ of FETR/ $\mathrm{kg}$ DM of TMR) has exhibited the best effect on nutrient digestibility. These findings are in agreement with previous studies that showed increasing in NDF digestibility due to adding fibrolytic enzymes rich in xylanase and cellulase to dairy cow diets (Rode et al., 1999; Yang et al., 1999; Salem et al., 2013). However, other studies have reported no effect of fibrolytic enzymes rich in xylanase and cellulase on NDF digestibility (Lewis et al., 1999; Knowlton et al., 2002; Peters et al., 2010). Large variations among studies exist in terms of the type of enzyme activity, the application of fibrolytic enzyme in ruminant diets (direct, mixed with ration with different preincubation time), dosage level, and the composition of the diet. These variabilities among studies resulted in discrepancies in the results of fibrolytic enzyme activities on digestibility in dairy cows. The enhanced effect of fibrolytic enzyme on nutrient digestibility in the current study would be attributed to the ability of FETR to improve microbial colonization (Yang et al., 1999) or to the positive synergy effect of FETR with the ruminal microorganisms (Colombatto and Beauchemin, 2003; Beauchemin and Holtshausen, 2010).

Table 4 shows the effect of fibrolytic enzyme level on milk production and composition. There were quadratic and cubic $(P<0.05)$ effects of FETR level on FCM and ECM, with the highest FCM and ECM at $0.75 \mathrm{~mL}$ of enzyme $/ \mathrm{kg}$ of TMR. In some studies, applying fibrolytic enzymes increased milk production (Lewis et al., 1999; Yang et al., 1999, 2000; Mohamed et al., 2013), but no milk response was reported in others (Elwakeel et al., 2007; Arriola et al., 2011; Peters et al., 2015). The effect of enzyme supplementation on milk yield in

Table 3. Effect of exogenous fibrolytic enzyme derived from Trichoderma reesei (FETR; mixture of xylanase and cellulase) levels on nutrient intake and total-tract nutrient digestibility in dairy cows

\begin{tabular}{|c|c|c|c|c|c|c|c|c|}
\hline Item & \multicolumn{4}{|c|}{ Enzyme level (mL of FETR/kg of DM of TMR) } & SEM & \multicolumn{3}{|c|}{ Polynomial contrast value } \\
\hline \multicolumn{9}{|c|}{ Intake $(\mathrm{kg} / \mathrm{d})$} \\
\hline $\mathrm{OM}$ & 25.46 & 25.56 & 25.84 & 25.42 & 0.412 & 0.808 & 0.448 & 0.380 \\
\hline NDF & 8.31 & 8.35 & 8.46 & 8.27 & 0.131 & 0.789 & 0.223 & 0.285 \\
\hline $\mathrm{pdNDF}^{1}$ & 4.55 & 4.62 & 4.74 & 4.56 & 0.074 & 0.357 & 0.072 & 0.068 \\
\hline OM & 66.42 & 65.00 & 68.51 & 67.00 & 0.924 & 0.299 & 0.548 & 0.024 \\
\hline $\mathrm{NDF}$ & 47.30 & 44.17 & 53.44 & 49.72 & 1.947 & 0.110 & 0.479 & 0.007 \\
\hline $\mathrm{pdNDF}^{2}$ & 79.59 & 72.94 & 88.64 & 83.08 & 3.946 & 0.226 & 0.406 & 0.023 \\
\hline
\end{tabular}

${ }^{1}$ Potentially digestible NDF.

${ }^{2}$ pdNDF digestibility $(\%)=100-[($ dietary indigestible NDF/fecal indigestible NDF $) \times($ fecal pdNDF concentration/dietary pdNDF $)]$. 
the current study would be attributed to improving the total-tract NDF digestibility, hence increasing energy density.

There was a quadratic response $(P=0.02$; Table 4$)$ of milk fat yield to FETR levels. Dietary differences in the composition of milk are normally related to changes in ruminal digestion. The higher milk fat yield resulted from an enhancement of fiber digestibility due to FETR supplementation. At the highest enzyme dosage, the dairy cows exhibited low milk fat percentage and milk fat yield. This finding is in line with a previous study that showed a reduction in milk fat content when applying a high level of enzymes rich in xylanase and cellulase to dairy cow diets (Yang et al., 1999). Decreases in milk fat would be attributed to decreases in ruminal acetate concentration due to applying enzymes to TMR. Acetate is the main lipogenic precursor in the mammary gland during lactation (Smith, 1983). Any reduction in acetate would in turn decrease the milk fat synthesis in the mammary gland and hence induce milk fat depression. Dean et al. (2013) reported a reduction in acetate:propionate ratio due to applying a fibrolytic enzyme product characterized by cellulase activity directly to TMR.

There was a linear increase $(P=0.04)$ in milk protein composition but not yield when applying enzyme to the TMR (Table 4). The greater protein synthesis in the mammary gland could be attributed to the higher nutrient flow to the mammary gland due to enhancing the nutrient digestibility as a consequence of FETR supplementation to dairy cows diets (Reynolds et al., 1994). The percentage of milk lactose tended to quadratically respond $(P=0.09)$ with increasing FETR levels (Table
4). The dosage of $0.75 \mathrm{~mL} / \mathrm{kg} \mathrm{DM}$ of TMR exhibited the best milk lactose percentage. The higher milk lactose content is related to an increase in the DM digestibility as a consequence of FETR supplementation. In agreement with this finding, Yang et al. (1999) reported an increase in milk lactose when applying fibrolytic enzymes rich in xylanase and cellulase to dairy cows during early lactation. Applying the enzymes tended to linearly $(P=0.10)$ increase the SNF percentage (Table 4). The SNF contains lactose, caseins, whey proteins, and minerals (ash content). This increase in SNF appeared to be entirely accounted for by the increase in milk protein and lactose. The milk urea content shown in this study is within the normal range, resulting from a diet with balanced protein supply and energy (Kirchgessner et al., 1986). The averaged MUN concentration was $11.9 \mathrm{mg} / \mathrm{dL}$ of milk, and application of FETR did not affect MUN concentration $(P>0.05)$.

Enzyme application tended to affect feed efficiency in a quadratic pattern $(P=0.07$; Table 4$)$. The diet with the highest dosage showed lower feed efficiency, expressed as FCM/DMI or ECM/DMI. The diet supplemented with $0.75 \mathrm{~mL} / \mathrm{kg}$ of TMR exhibited higher feed efficiency and higher FCM yield compared with the other doses. These findings indicate that supplementing the forage with moderate enzyme levels could enhance dairy cow performance. These findings are in agreement with previous studies (Lewis et al., 1999; Klingerman et al., 2009; Arriola et al., 2011). However, other studies did not detect any change (Schingoethe et al., 1999; Kung et al., 2002; Bernard et al., 2010). This discrepancy among studies could be due to variances in enzymatic activity, level of application, lactation

Table 4. Effect of exogenous fibrolytic enzyme derived from Trichoderma reesei (FETR; mixture of xylanase and cellulase) levels on milk yield, milk composition, and feed efficiency in lactating dairy cows

\begin{tabular}{|c|c|c|c|c|c|c|c|c|}
\hline \multirow[b]{2}{*}{ Item } & \multicolumn{4}{|c|}{ Enzyme level (mL of FETR/kg of DM of TMR) } & \multirow[b]{2}{*}{ SEM } & \multicolumn{3}{|c|}{ Polynomial contrast value } \\
\hline & Control (0) & 0.50 & 0.75 & 1.00 & & Linear & Quadratic & Cubic \\
\hline Milk & 38.63 & 38.22 & 39.33 & 38.42 & 2.074 & 0.783 & 0.814 & 0.036 \\
\hline FCM & 36.35 & 37.32 & 38.87 & 33.81 & 1.793 & 0.365 & 0.013 & 0.056 \\
\hline $\mathrm{ECM}$ & 36.76 & 37.26 & 38.94 & 34.72 & 1.619 & 0.406 & 0.017 & 0.028 \\
\hline Fat & 1.21 & 1.28 & 1.35 & 1.07 & 0.083 & 0.398 & 0.017 & 0.122 \\
\hline SNF & 3.32 & 3.30 & 3.43 & 3.32 & 0.169 & 0.437 & 0.630 & 0.019 \\
\hline \multicolumn{9}{|l|}{ Milk composition } \\
\hline Fat $(\%)$ & 3.12 & 3.05 & 3.28 & 2.85 & 0.195 & 0.359 & 0.189 & 0.062 \\
\hline Protein $(\%)$ & 3.16 & 3.18 & 3.24 & 3.21 & 0.087 & 0.039 & 0.795 & 0.150 \\
\hline Lactose (\%) & 4.46 & 4.52 & 4.54 & 4.49 & 0.038 & 0.147 & 0.085 & 0.396 \\
\hline $\mathrm{TS}(\%)$ & 11.58 & 11.50 & 11.83 & 11.39 & 0.242 & 0.759 & 0.275 & 0.025 \\
\hline $\operatorname{SNF}(\%)$ & 8.62 & 8.63 & 8.73 & 8.72 & 0.099 & 0.104 & 0.791 & 0.315 \\
\hline
\end{tabular}


Table 5. Effect of exogenous fibrolytic enzyme derived from Trichoderma reesei (FETR; mixture of xylanase and cellulase) levels on feeding behavior

\begin{tabular}{|c|c|c|c|c|c|c|c|}
\hline \multirow[b]{2}{*}{ Item } & \multicolumn{4}{|c|}{ Enzyme level (mL of FETR/kg of DM of TMR) } & \multirow[b]{2}{*}{ SEM } & \multicolumn{2}{|c|}{ Polynomial contrast value } \\
\hline & Control (0) & 0.50 & 0.75 & 1.00 & & Linear & Quadratic \\
\hline Meal length (min) & 26.3 & 28.8 & 27.3 & 27.2 & 1.95 & 0.727 & 0.367 \\
\hline Eating rate $(\mathrm{g} / \mathrm{min})$ & 124.6 & 122.3 & 125.1 & 124.9 & 4.84 & 0.866 & 0.607 \\
\hline \multicolumn{8}{|l|}{ Meal size $(\mathrm{kg})$} \\
\hline NDF & 1.0 & 1.1 & 1.0 & 1.0 & 0.06 & 0.621 & 0.285 \\
\hline $\operatorname{pdNDF}^{1}$ & 0.5 & 0.6 & 0.6 & 0.6 & 0.03 & 0.581 & 0.231 \\
\hline
\end{tabular}

${ }^{1}$ Potentially digestible NDF.

stage, mode and time of enzyme application, enzyme feed specificity, and the part of the diet to which enzymes are applied (Beauchemin et al., 2004; Adesogan, 2005). The low feed efficiency of the highest enzyme level is attributed to its adverse effect on milk fat yield. In a meta-analysis, Arriola et al. (2017) reported that increasing the rate of enzyme application did not affect feed efficacy in dairy cows. A negative effect of fibrolytic enzyme supplementation on feed efficiency was reported by Dean et al. (2013) when they applied the fibrolytic enzyme rich in cellulase directly to TMR.

The effect of enzymes on feeding behavior is presented in Table 5 . There was no effect $(P>0.10)$ of enzyme level on feeding behavior. The lacking effect is attributed to no effect of enzymes on feed intake. The results in the current study agree with previous studies reporting that fibrolytic supplementation had no effect on eating or rumination activities (Bowman et al., 2002; Peters et al., 2015). Other studies have reported positive effects of enzyme addition on feeding behavior; for example, Gandra et al. (2017) reported an increase in eating time for Jersey heifers fed either corn silageor sugarcane silage-based diets treated with fibrolytic enzymes. Further study by He et al. (2015) found that eating time and bunk attendance frequency increased when fibrolytic enzymes were added to the diet of beef heifers. Silva et al. (2016) found that total chewing activities (rumination and eating) increased with fibrolytic enzyme supplementation. This inconsistency across studies could be attributed to differences in enzymatic activity, level of application, lactation stage, and mode and time of enzyme application (Beauchemin et al., 2004).

Pretreating dairy cow barley-based TMR with FETR improved dairy cow performance during the mid-lactation phase. Based on the current study, the optimum dosage of the fibrolytic enzymes was $0.75 \mathrm{~mL}$ of FETR/ $\mathrm{kg}$ DM of TMR. Applying this dosage improved NDF digestibility, fat yield, FCM yield, and feed efficiency of dairy cows fed a diet containing $34 \%$ barley silage (DM basis).

\section{ACKNOWLEDGMENTS}

The authors thank Niu and Morgen Horbin (University of Saskatchewan, Canada) for their helpful assistance with the project. Financial support for SRP Feed Research Chair (P. Yu) from the Saskatchewan Ministry of Agriculture Strategic Research Chair Programs in Feeds R\&D, the Natural Sciences and Engineering Research Council of Canada, the Saskatchewan Agriculture Development Fund (Saskatoon, Canada), SaskMilk, the Saskatchewan Forage Network, and Western Grain Research Foundation is acknowledged. The authors acknowledge AB Vista (Wiltshire, UK) for providing samples of their commercial products for use in this study.

\section{REFERENCES}

Adesogan, A. T. 2005. Improving forage quality and animal performance with fibrolytic EFEs. Pages 91-109 in Proc. 16th Florida Ruminant Nutrition Symposium, University of Florida, Gainesville.

Ahvenjärvi, S., A. Vanhatalo, P. Huhtanen, and T. Varvikko. 2000. Determination of forestomach digestion in lactating dairy cows by omasal or duodenal sampling. Br. J. Nutr. 83:67-77.

Allen, M. S. 1996. Physical constraints on voluntary intake of forages by ruminants. J. Anim. Sci. 74:3063-3075.

AOAC. 1990. Official Methods of Analysis. 15th ed. Association of Official Analytical Chemists, Arlington, VA.

AOAC International. 2000. Official Methods of Analysis. 17th ed. AOAC International, Gaithersburg, MD.

Arriola, K. G., S. C. Kim, C. R. Staples, and A. T. Adesogan. 2011. Effect of fibrolytic enzyme application to low- and high-concentrate diets on the performance of lactating dairy cattle. J. Dairy Sci. 94:832-841. https://doi.org/10.3168/jds.2010-3424.

Arriola, K. G., A. S. Oliveira, Z. X. Ma, I. J. Lean, M. C. Giurcanu, and A. T. Adesogan. 2017. A meta-analysis on the effect of dietary application of exogenous fibrolytic enzymes on the performance of dairy cows. J. Dairy Sci. 100:4513-4527. https://doi.org/10.3168/ jds.2016-12103.

Beauchemin, K. A., D. Colombatto, D. P. Morgavi, W. Z. Yang, and L. M. Rode. 2004. Mode of action of exogenous cell wall degrading 
enzymes for ruminants. Can. J. Anim. Sci. 84:13-22. https://doi .org/10.4141/A02-102.

Beauchemin, K. A., and L. Holtshausen. 2010. Enzymes in Farm Animal Nutrition. M. R. Bedford and G. G. Partridge, ed. CABI, Wallingford, UK.

Beauchemin, K. A., L. M. Rode, M. Maekawa, D. P. Morgavi, and R. Kampen. 2000. Evaluation of a nonstarch polysaccharidase feed enzyme in dairy cow diets. J. Dairy Sci. 83:543-553. https://doi .org/10.3168/jds.S0022-0302(00)74914-9.

Beauchemin, K. A., L. M. Rode, and V. J. H. Sewaltl. 1995. Fibrolytic enzymes increase fiber digestibility and growth rate of steers fed dry forages. Can. J. Anim. Sci. 75:641-644. https://doi.org/10 .4141/cjas95-096.

Bernard, J. K., J. J. Castro, N. A. Mullis, A. T. Adesogan, J. W. West, and G. Morantes. 2010. Effect of feeding alfalfa hay or Tifton 85 bermudagrass haylage with or without a cellulase enzyme on performance of Holstein cows. J. Dairy Sci. 93:5280-5285. https://doi .org/10.3168/jds.2010-3111.

Bowman, G. R., K. A. Beauchemin, and J. A. Shelford. 2002. The proportion of the diet to which fibrolytic enzymes are added affects nutrient digestion by lactating dairy cows. J. Dairy Sci. 85:34203429. https://doi.org/10.3168/jds.S0022-0302(02)74430-5.

Chow, L. O. O., V. S. S. Baron, R. Corbett, and M. Oba. 2008. Effects of planting date on fiber digestibility of whole-crop barley and productivity of lactating dairy cows. J. Dairy Sci. 91:1534-1543.

Chung, Y.-H., M. Zhou, L. Holtshausen, T. W. Alexander, T. A. McAllister, L. L. Guan, M. Oba, and K. A. Beauchemin. 2012. A fibrolytic enzyme additive for lactating Holstein cow diets: Ruminal fermentation, rumen microbial populations, and enteric methane emissions. J. Dairy Sci. 95:1419-1427. https://doi.org/10 $.3168 /$ jds.2011-4552.

Colombatto, D., and K. A. Beauchemin. 2003. A proposed methodology to standardize the determination of enzymic activities present in enzyme additives used in ruminant diets. Can. J. Anim. Sci. 83:559-568.

Dado, R. G., and M. S. Allen. 1995. Intake limitations, feeding behavior, and rumen function of cows challenged with rumen fill from dietary fiber or inert bulk. J. Dairy Sci. 78:118-133.

Dean, D. B., C. R. Staples, R. C. Littell, S. Kim, and A. T. Adesogan. 2013. Effect of method of adding a fibrolytic enzyme to dairy cow diets on feed intake digestibility, milk production, ruminal fermentation, and blood metabolites. Anim. Nutr. Feed Technol. 13:337-353.

Elwakeel, E. A., E. C. Titgemeyer, B. J. Johnson, C. K. Armendariz, and J. E. Shirley. 2007. Fibrolytic enzymes to increase the nutritive value of dairy feedstuffs. J. Dairy Sci. 90:5226-5236. https:// doi.org/10.3168/jds.2007-0305.

Eun, J.-S., K. A. Beauchemin, and H. Schulze. 2007. Use of exogenous fibrolytic enzymes to enhance in vitro fermentation of alfalfa hay and corn silage. J. Dairy Sci. 90:1440-1451. https://doi.org/10 .3168/jds.S0022-0302(07)71629-6.

Fustini, M., A. Palmonari, G. Canestrari, E. Bonfante, L. Mammi, M. T. Pacchioli, G. C. J. Sniffen, R. J. Grant, K. W. Cotanch, and A. Formigoni. 2017. Effect of undigested neutral detergent fiber content of alfalfa hay on lactating dairy cows: Feeding behavior, fiber digestibility, and lactation performance. J. Dairy Sci. 100:4475-4483. https://doi.org/10.3168/jds.2016-12266.

Gado, H. M., A. Z. M. Salem, P. H. Robinson, and M. Hassan. 2009 Influence of exogenous enzymes on nutrient digestibility, extent of ruminal fermentation as well as milk production and composition in dairy cows. Anim. Feed Sci. Technol. 154:36-46. https://doi .org/10.1016/j.anifeedsci.2009.07.006.

Gandra, J. R., G. A. Miranda, R. H. T. B. Goes, C. S. Takiya, T. A. Del Valle, E. R. Oliveira, J. E. Freitas Jr., E. R. S. Gandra, H. M. C. Araki, and A. L. A. V. Santos. 2017. Fibrolytic enzyme supplementation through ruminal bolus on eating behavior, nutrient digestibility and ruminal fermentation in Jersey heifers fed either corn silage- or sugarcane silage-based diets. Anim. Feed Sci. Technol. 231:29-37. https://doi.org/10.1016/j.anifeedsci.2017.06.009.

He, Z. X., N. D. Walker, T. A. McAllister, and W. Z. Yang. 2015. Effect of wheat dried distillers grains with solubles and fibrolytic en- zymes on ruminal fermentation, digestibility, growth performance, and feeding behavior of beef cattle. J. Anim. Sci. 93:1218-1228. https://doi.org/10.2527/jas.2014-8412.

Kirchessner, M., M. Kreuzer, and D. A. Roth-Maier. 1986. Milk urea and protein content to diagnose energy and protein malnutrition of dairy cows. Arch. Tierernahr. 36:192-197. https://doi.org/10 $.1080 / 17450398609425260$.

Klingerman, C. M., W. Hu, E. E. McDonell, M. C. DerBedrosian, and L. Kung Jr.. 2009. An evaluation of exogenous EFEs with amylolytic activity for dairy cows. J. Dairy Sci. 92:1050-1059.

Knowlton, K. F., J. M. McKinney, and C. Cobb. 2002. Effect of a direct-fed fibrolytic enzyme formulation on nutrient intake, partitioning, and excretion in early and late lactation Holstein cows. J. Dairy Sci. 85:3328-3335.

Kung, L., M. A. Cohen, L. M. Rode, and R. J. Treacher. 2002. The effect of fibrolytic enzymes sprayed onto forages and fed in a total mixed ratio to lactating dairy cows. J. Dairy Sci. 85:2396-2402. https://doi.org/10.3168/jds.S0022-0302(02)74321-X.

Kung, L., R. J. Treacher, G. A. Nauman, A. M. Smagala, K. M. Endres, and M. A. Cohen. 2000. The effect of treating forages with fibrolytic enzymes on its nutritive value and lactation performance of dairy cows. J. Dairy Sci. 83:115-122. https://doi.org/10.3168/ jds.S0022-0302(00)74862-4.

Lewis, G. E., W. K. Sanchez, C. W. Hunt, M. A. Guy, G. T. Pritchard, B. I. Swanson, and R. J. Treacher. 1999. Effect of direct-fed fibrolytic enzymes on the lactational performance of dairy cows. J. Dairy Sci. 82:611-617. https://doi.org/10.3168/jds.S0022 $-0302(99) 75274-4$

Mauricio, R. M., F. L. Mould, M. S. Dhanoa, E. Owen, K. S. Channa, and M. K. Theodorou. 1999. A semi-automated in vitro gas production technique for ruminant feedstuff evaluation. Anim. Feed Sci. Technol. 79:321-330.

McAllister, T. A., S. J. Oosting, J. D. Popp, Z. Mir, L. J. Yanke, A. N. Hristov, R. J. Treacher, and K.-J. Cheng. 1999. Effect of exogenous enzymes on digestibility of barley silage and growth performance of feedlot cattle. Can. J. Anim. Sci. 79:353-360. https://doi .org/10.4141/A98-099.

Mohamed, D. E.-D. A., B. E. Borhami, K. A. El-Shazly, and S. M. A Sallam. 2013. Effect of dietary supplementation with fibrolytic enzymes on the productive performance of early lactating dairy cows. J. Agric. Sci. 5:146-155. https://doi.org/10.5539/jas.v5n6p146.

Nair, J., D. Christensen, P. Yu, T. Mcallister, N. Preston, D. Damiran, and J. J. Mckinnon. 2017. Effect of variety and level of inclusion of barley varieties for silage selected to vary in neutral detergent fiber digestibility on performance and carcass characteristics of growing and finishing beef steers. Can. J. Anim. Sci. 97:383-394.

NRC (National Research Council). 2001. Nutrient Requirements of Dairy Cattle. 7th rev. ed. National Academy Press, Washington, DC.

Oba, M., and M. S. S. Allen. 2000. Effects of brown midrib 3 mutation in corn silage on productivity of dairy cows fed two concentrations of dietary neutral detergent fiber: 1 . Feeding behavior and nutrient utilization. J. Dairy Sci. 83:1333-1341. https://doi.org/10.3168/ jds.S0022-0302(00)75000-4.

Peters, A., P. Lebzien, U. Meyer, U. Borchert, M. Bulang, and G. Flachowsky. 2010. Effect of exogenous fibrolytic enzymes on ruminal fermentation and nutrient digestion in dairy cows. Arch. Anim. Nutr. 64:221-237.

Peters, A., U. Meyer, and S. Dänicke. 2015. Effect of exogenous fibrolytic enzymes on performance and blood profile in early and midlactation Holstein cows. Anim. Nutr. 1:229-238. https://doi.org/ 10.1016/j.aninu.2015.09.001.

Poppi, D. P. 2011. Nutritional constraints for grazing animals and the importance of selective grazing behaviour. Pages 19-26 in Grassland Productivity and Ecosystem Services. G. Lemaire, J. Hodgson, and A. Chabbi, ed. CABI, Wallingford, UK.

Reynolds, C. 2000. Forage evaluation using measurements of energy metabolism. Pages 95-111 in Forage Evaluation in Ruminant $\mathrm{Nu}-$ trition. D. I. Givens, E. Owen, R. F. E. Axford, and H. M. Omed, ed. CABI, Wallingford, UK. 
Reynolds, C. K., D. L. Harmon, and M. J. Cecava. 1994. Absorption and delivery of nutrients for milk protein synthesis by portaldrained viscera. J. Dairy Sci. 77:2787-2808. https://doi.org/10 .3168/jds.S0022-0302(94)77220-9.

Salem, A. Z. M., H. M. Gado, D. Colombatto, and M. M. Y. Elghandour. 2013. Effects of exogenous enzymes on nutrient digestibility, ruminal fermentation and growth performance in beef steers. Livest. Sci. 154:69-73. https://doi.org/10.1016/j.livsci.2013.02.014.

Schingoethe, D. J., G. A. Stegeman, and R. J. Treacher. 1999. Response of lactating dairy cows to a cellulase and xylanase EFE mixture applied to forages at the time of feeding. J. Dairy Sci. 82:996-1003.

Silva, T. H., C. S. Takiya, T. H. A. Vendramini, E. F. de Jesus, F. Zanferari, and F. P. Rennó. 2016. Effects of dietary fibrolytic enzymes on chewing time, ruminal fermentation, and performance of mid-lactating dairy cows. Anim. Feed Sci. Technol. 221:35-43. https://doi.org/10.1016/j.anifeedsci.2016.08.013.

Smith, S. B. 1983. Contribution of the pentose cycle to lipogenesis in bovine adipose tissue. Arch. Biochem. Biophys. 221:46-56.

Titi, H. H. 2003. Evaluation of feeding a fibrolytic enzyme to lactating dairy cows on their lactational performance during early lactation. Asian-australas. J. Anim. Sci. 16:677-684.
Urrutia, N., and K. J. Harvatine. 2017. Effect of conjugated linoleic acid and acetate on milk fat synthesis and adipose lipogenesis in lactating dairy cows. J. Dairy Sci. 100:5792-5804.

Van Soest, P. J., J. B. Robertson, B. A. Lewis, C. J. Sniffen, J. W. Devries, C. J. Sniffen, and R. W. Mailman. 1991. Methods for dietary fiber, neutral detergent fiber, and nonstarch polysaccharides in relation to animal nutrition. J. Dairy Sci. 74:3583-3597. https://doi.org/10.3168/jds.S0022-0302(91)78551-2.

Wallsten, J., and R. Hatfield. 2016. Cell wall chemical characteristics of whole-crop cereal silages harvested at three maturity stages. J. Sci. Food Agric. 96:3604-3612. https://doi.org/10.1002/jsfa.7736.

Yang, W. Z., K. A. Beauchemin, and L. M. Rode. 1999. Effects of an enzyme feed additive on extent of digestion and milk production of lactating dairy cows. J. Dairy Sci. 82:391-403. https://doi.org/ 10.3168/jds.S0022-0302(99)75245-8.

Yang, W. Z., K. A. Beauchemin, and L. M. Rode. 2000. A comparison of methods of adding fibrolytic enzymes to lactating cow diets. J. Dairy Sci. 83:2512-2520. https://doi.org/10.3168/jds.S0022 $-0302(00) 75143-5$. 